\title{
A synopsis of Middle East Filistata (Aranei: Filistatidae), with description of a new species from Azerbaijan
}

\section{Обзор переднеазиатских видов рода Filistata (Aranei: Filistatidae), с описанием нового вида из Азербайджана}

\author{
Yuri M. Marusik ${ }^{1,2} \&$ Sergei L. Zonstein ${ }^{3}$ \\ Ю.M. Marusik ${ }^{1,2}$, С. $\Lambda$. Зонштейн ${ }^{3}$

\begin{abstract}
${ }^{1}$ Institute for Biological Problems of the North RAS, Portovaya Str. 18, Magadan 685000 Russia. E-mail: yurmar@mail.ru 'Институт биологических проблем Севера ДВО РАН, Портовая 18, Магадан 685000, Россия.

${ }^{2}$ Zoological Museum, University of Turku, FI-20014 Turku, Finland.

${ }^{3}$ Department of Zoology, The George S. Wise Faculty of Life Sciences, Tel-Aviv University, 69978 Tel-Aviv, Israel. E-mail: znn@post.tau.ac.il
\end{abstract}

KEY WORDS: Spider, cribellate, new species, distribution, taxonomy, Naxçývan, Turkey, Iran.

КЛЮЧЕВЫЕ СЛОВА: Паук, крибеллятный, новый вид, распространение, таксономия, Нахичевань, Турция, Иран.

ABSTRACT. A survey of Filistata Latreille, 1810 occurring in the Middle East is provided. Two species occur in region: the trans-Mediterranean $F$. insidiatrix (Forsskål, 1775) and the new species, F. lehtineni sp.n., from Azerbaijan. The two species are illustrated and a detailed description is provided for the new species. The distribution of $F$. insidiatrix is briefly discussed and a map showing the ranges of both species is presented.

РЕЗЮМЕ. Сделан обзор пауков рода Filistata Latreille, 1810 Передней Азии. В регионе выявлены два вида: транссредиземноморский $F$. insidiatrix (Forsskål, 1775) и новый вид, F. lehtineni sp.n., из Азербайджана. Оба вида проиллюстрированы и новый вид подробно описан. Обсуждено вкратце распространение $F$. insidiatrix и приведена карта с распространением обоих видов.

\section{Introduction}

Currently Filistata Latreille, 1810, with 18 valid species, is second largest genus of the family Filistatidae [Platnick, 2014]. Only Pritha Lehtinen, 1967 has more species (20) [Platnick, 2014]. Most species of Filistata are known from the southern Palaearctic (from the Canary Islands to Japan), although three species are known outside of the Palaearctic: Mexico, India and Christmas Island [cf. Platnick, 2014]. The genus is rather poorly studied and has not been the subject of a large scale taxonomic revision. The majority of species (10) are known from a single taxonomic entry, another four species are known from only two entries [cf. Platnick, 2014]. Eight species are known from a single sex, either the female (seven species) or the male (one spe- cies). Species known only from females lack illustrations of the endogyne. The largest contribution to the taxonomy of the genus was made by Wunderlich, who revised Filistata of the Canary Islands and also, in part, the south Mediterranean taxa [Wunderlich, 1992, 1995]. Judging from the original descriptions (indication of size, position of spinnerets, shape of the male palp, etc.) and the study of some types, the species that occur outside of the Mediterranean are likely misplaced in the genus.

Only one species of the genus, $F$. insidiatrix (Forsskål, 1775), has a wide range and occurs from the Iberian Peninsula to Turkmenistan [Helsdingen, 2013; Mikhailov, 2013]. Other species are known from either their type locality only, or from a few additional nearby regions. The highest species diversity of the genus is observed in the Mediterranean (nine) [cf. Helsdingen, 2013], and within this region the highest diversity occurs in Macaronesia (five species). The eastern Mediterranean harbors only three species: $F$. annulipes Kulczyński, 1908, F. insidiatrix and $F$. puta O. PickardCambridge, 1876 [Mikhailov, 2013; Platnick, 2014]. While surveying the fauna of Azerbaijan, the senior author collected $F$. insidiatrix and another unidentifiable species. The main goals of this paper are as follows: 1) to describe the new species in detail and 2) to clarify the distribution of $F$. insidiatrix.

\section{Material and methods}

Photographs were taken using an Olympus E-520 camera attached to an Olympus SZX16 stereomicroscope, and prepared using CombineZP image stacking software. Epigynes were cleared in a $\mathrm{KOH} /$ water solution. Photographs were taken with the specimens se- 


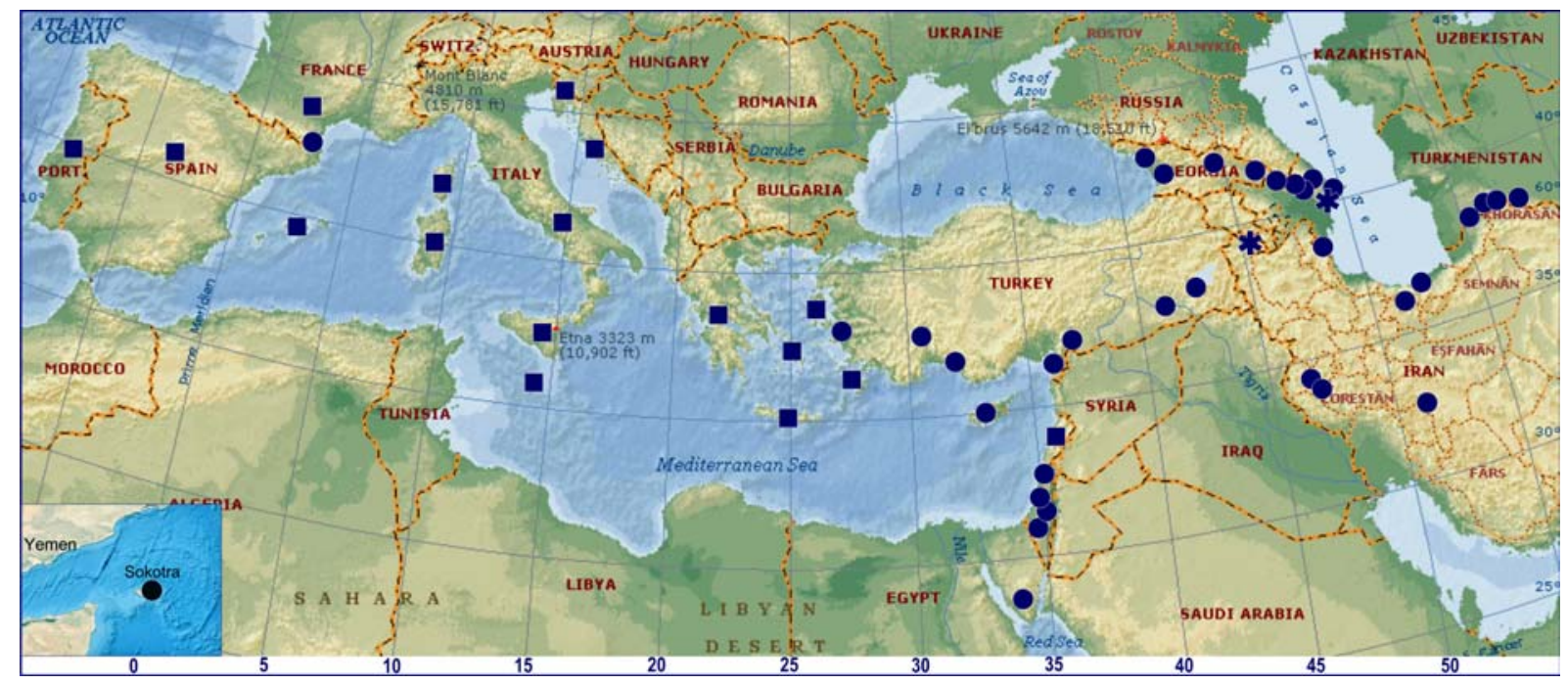

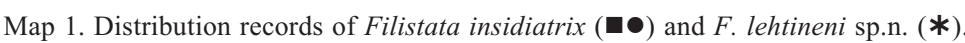

Square ( $)$ refers to state or island record in Helsdingen [2013] and circle (๑) refers to examined material (by us or our colleagues).

Карта 1. Распространение Filistata insidiatrix ( $\boldsymbol{\bullet})$ и F. lehtineni sp.n. (*).

Квадратом (ש) отмечены страны или острова где встречается вид согласно Helsdingen [2013] и кружком (•) отмечены локалитеты из которых мы или наши коллеги исследовали материал.

cured in dishes with paraffin on bottom. Measurements were made to an accuracy of $0.01 \mathrm{~mm}$. Lengths of leg and palp segments were measured on the dorsal side, from the midpoint of the anterior margin to the midpoint of the posterior margin. All measurements are given in millimetres.

Specimens from the following spider collections were studied: HUJ - Hebrew University, Jerusalem, Israel; MMUM - Manchester Museum, the University of Manchester; TAU - Department of Zoology, Tel-Aviv University, Israel; ZMMU - Zoological Museum of the Moscow State University, Russia; ZMUT - Zoological Museum, University of Turku, Finland.

The abbreviations used in the text are as follows. Eyes: ALE - anterior lateral; AME - anterior median; PLE - posterior lateral; PME — posterior median. Leg and palp segments: F — femur; $\mathrm{M}$ - metatarsus; $\mathrm{T}$ - tibia. Spines and their position: $\mathrm{d}$ - dorsal; $\mathrm{p}$ prolateral; $\mathrm{r}$ - retrolateral; $\mathrm{v}$ - ventral.

\section{Taxonomy}

Filistata Latreille, 1810

Filistata Latreille, 1810: 121.

Type species: Filistata testacea Latreille, 1810 (= Aranea insidiatrix Forsskål, 1775) by monotypy).

Filistata insidiatrix (Forsskål, 1775)

Figs 1-3, 7-8, 11-12, 15-16, 19-22, 25-27, Map 1.

F. i.: Brignoli, 1978: 288, f. 1-3, 9 ( $\left.\sigma^{\top}+\right)$.

F. i.: Brignoli, 1982: 68, f. 1-5 ( $\left.\sigma^{\top}+\right)$.

F. i.: Wunderlich, 2011: 173, f. 1-1a $\left(\sigma^{7}\right)$.

For a complete list of references see Platnick [2013].
Selected records of $F$. insidiatrix east of Turkey in the eastern Mediterranean: Strand, 1913: 147; Spassky, 1952: 194; Roewer, 1959: 33; Brignoli, 1982: 68; Dunin, 1984: 52; Dunin, 1988: 191; Fet, 1983: 836; Mkheidze, 1997: 50; Ghahari \& Marusik, 2009: 3; Kunt et al., 2008: 683.

MATERIAL EXAMINED. FRANCE: $2 \sigma^{7} \sigma^{7}, 3$ 오 (MMUM), Pyrénées Orientales, Banyuls-sur-Mer, no dates (J. Denis). EGYPT: Sinai: 3 juv. (HUJ), Wadi Kuni, 26.01.1968 (E. Reichenstein); 1 juv. (HUJ), Ein-Chadijeh, 21.04.1968 (A. Shulov); 1 juv. (HUJ), Wadi E'Shech, 19-22.07.1968 (A. Shulov); 1 juv. (HUJ), Wadi Mahlafa, 5.09.1968 (G. Tsabar); 1 juv. (HUJ), En-Zeituna, 6.09.1968 (G. Tsabar); 1 juv. (HUJ), Wadi Ysla, 9.09.1968 (G. Tsabar). TURKEY: Izmir Prov.: 2 0 (ZMMU), Vi ${ }^{\circ}$ neli Village (Fetrek-2 Cave), 38 $20.7^{\prime} \mathrm{N} 2^{\circ} 25.3^{\prime} \mathrm{E}, 310 \mathrm{~m}, 5.06 .2009$ (Y.M. Marusik); Antalya Prov.: 1 ㅇ (MMUM), Kalkan (36 $\left.16^{\prime} \mathrm{N} 29^{\circ} 25^{\prime} \mathrm{E}\right)$, 1-30.06.2002 (L. Cook); 8 우 4 subad. ㅇ (ZMMU), Alanya Dist., Avsallar Town, $36^{\circ} 38^{\prime} 21.5^{\prime \prime} \mathrm{N} 31^{\circ} 45^{\prime} 24.9^{\prime \prime} \mathrm{E}, 7 \mathrm{~m}$, grotto, on the roof, walls and among clay-sand piles, 6.01.2013 (Y.M. Marusik). CYPRUS: 1 ( (TAU), Larnaca, 9.04.2008 (L. Friedman). ISRAEL (selected localities only): 1 + (HUJ), Upper Galilee, Ye'hiam, cave $\left(33^{\circ} 00^{\prime} \mathrm{N} 35^{\circ} 13^{\prime} \mathrm{E}\right), 15.11 .1949$ (A. Shulov); 3 우 (TAU), Mt. Meron, near the summit, $\left(32^{\circ} 59.8^{\prime} \mathrm{N} 35^{\circ} 24.7^{\prime} \mathrm{E}\right), 1100 \mathrm{~m}$, 20.05.2013 (S. Zonstein); 1 우 (HUJ), Lake Kinneret, Ginossar, 16.07.1967 (A. Shulov); 8 우 (TAU), same area, Digit, $32^{\circ} 51^{\prime} \mathrm{N}$ $35^{\circ} 396^{\prime} \mathrm{E},-200 \mathrm{~m}, 14.09 .2009$ (S. Zonstein); 2 우, 1 juv. (HUJ),

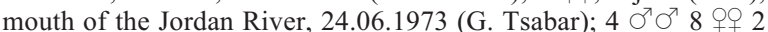
juv. (ZMMU), Haifa, University campus, $32^{\circ} 45^{\prime} \mathrm{N} 35^{\circ} 01^{\prime} \mathrm{E}, 450$ m, 29.12.2010 (Y.M. Marusik); 1 (TAU), Carmel Ridge, Nahal

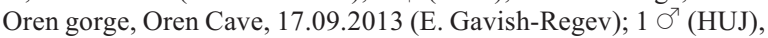
Tel-Aviv, 17.01.1951 (A. Shulov); 1 9 (HUJ), Jerusalem, 28.06.1954 (P. Amitai); 1 ठ (HUJ), same locality, 11.02 .1979 (G. Levy); $1 \sigma^{7}$, 1 q (TAU), Judean Hills, Nat. Park Adullam, 15.04.2003 (U. Columbus \& T. Levanony); 1 + (TAU), Northwestern Negev, $4 \mathrm{~km} \mathrm{E}$ Ze'elim, $31^{\circ} 13.7^{\prime} \mathrm{N} 34^{\circ} 35.2^{\prime} \mathrm{E}, 170 \mathrm{~m}, 10.02 .2012$ (E. GavishRegev); 1 (HUJ), Central Negev, Yeruham, 5.03.1961 (P. Amitai). IRAN: Kordestan Prov.: $10^{7}, 2$ 우 (ZMMU), Sanandaj $\left(35^{\circ} 19^{\prime} \mathrm{N} 47^{\circ} 00^{\prime} \mathrm{E}\right)$ and Marivan $\left(35^{\circ} 32^{\prime} \mathrm{N} 46^{\circ} 10^{\prime} \mathrm{E}\right)$, no date $(\mathrm{H}$. Ghahari); Esfahan Prov.: $1 \Im^{\top}$ (TAU), env. of Esfahan $\left(32^{\circ} 40^{\prime} \mathrm{N}\right.$ 51 $\left.{ }^{\circ} 40^{\prime} \mathrm{E}\right), 11.2001$ (H. Ghahari); $1 \mathrm{O}^{7}$ (TAU), same locality, 11.2005 (H. Ghahari); Mazandaran Prov.: $3 \sigma^{\top} \sigma^{\top}, 5$ 5 , 1 subad., 7 juv. (ZMMU), Ghaemshahr (= Qaemshahr, = Qa'emshahr), ca. $36^{\circ} 28^{\prime} \mathrm{N}$ $52^{\circ} 51^{\prime} \mathrm{E}$, citrus orchards, 07.2005 (H. Ghahari). AZERBAJAN: 1 우 (TAU) Zakataly $\left(41^{\circ} 38^{\prime} \mathrm{N} 46^{\circ} 39^{\prime} \mathrm{E}\right), 15.07 .1973$ (P.M. Dunin); 6 


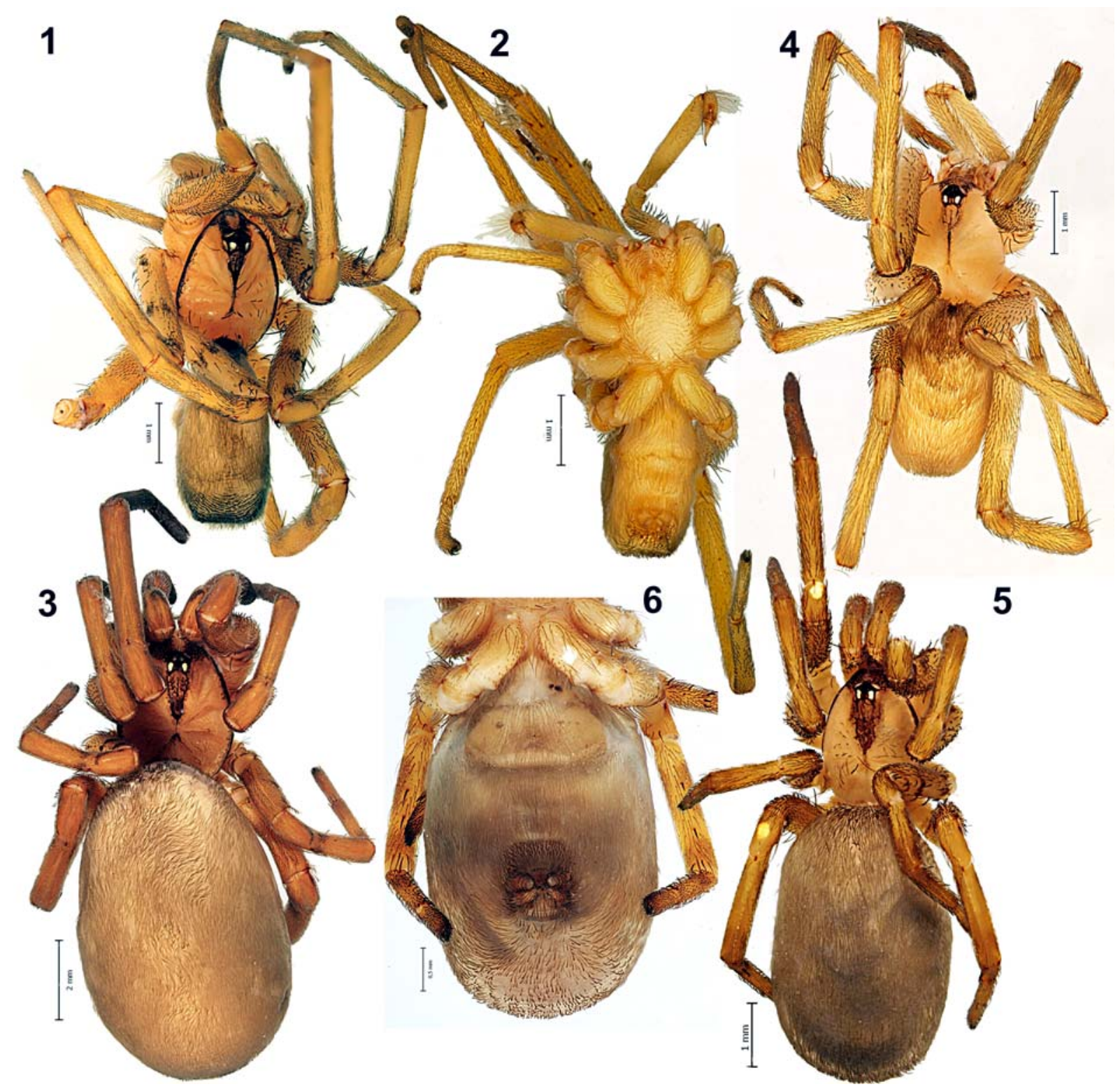

Figs 1-6. Habitus of Filistata insidiatrix (1-3) and F. lehtineni sp.n. (4-6): 1, 4 - male, dorsal; 2 - male, ventral; 3, 5 - female, dorsal; 6 - female abdomen, ventral.

Рис. 1-6. Габитус Filistata insidiatrix (1-3) и F. lehtineni sp.n. (4-6): 1, 4 - самец, сверху; 2 - самец, снизу; 3, 5 - самка, сверху; 6 - брюшко самки, снизу.

우 (ZMMU), Evlakh, 26-27.08.1977 (P.M. Dunin); 3 우 (TAU), Baku, city park, 19.04.1985 \& 26.03.1988 (O.H. Aslamov); 1 ठ (TAU), $25 \mathrm{~km} \mathrm{E}$ of Baku, Zirya, 15.05.1987 (P.M. Dunin); 1 ㅇ (TAU) 10 km E Baku, Mardakyan, 20.05.1987 (P.M. Dunin); 4 우 (TAU), same locality, 03.1988 (O.H. Aslamov); 1 juv. (ZMMU), Umbaki Mts. WSW of Baku, montain semidesert, 19.04.2001 (Y.M. Marusik); 2 우 subad. (ZMMU) Djalil'abad Dist., Farzam, 20.04.1987 (P.M. Dunin); Lenkoran Dist.: 1 q subad. (ZMMU), Lenkoran, 3-5.01.1980 (P.M. Dunin); 3 오, 1 juv. (ZMMU), Alekseevka, 18.07.1982 (D.V. Logunov) ; $20^{7} \sigma^{7}, 16$ 우, 3 우 subad., 4 juv. (ZMMU), Aurora $\left(38^{\circ} 40^{\prime} \mathrm{N} 48^{\circ} 47^{\prime} \mathrm{E}\right), 23-28.04 .2001$ (Y.M. Marusik); 10 우, 2 우 subad. (ZMMU), same locality, 2129.05.2003 (Y.M. Marusik). TURKMENISTAN: 2 우우 subad. (ZMMU), foothills of North-Western Kopetdagh Mts., Kov-Ata Cave in surroundings of Bakharden $\left(38^{\circ} 26^{\prime} \mathrm{N} 57^{\circ} 26^{\prime} \mathrm{E}\right), 18.07 .1929$ (J.P. Vlasov); 1 q subad., 3 juv. (ZMMU), same locality, 4-
5.02.1982 (K.G. Mikhailov); 1 +, 1 juv. (ZMMU), South-Western Kopetdagh Mts., Kara-Kala, 400 m, 15.07 .1985 (V.Y. Fet). YEMEN: 1 (TAU), Socotra Isl., Diksam Plateau $\left(12^{\circ} 30^{\prime} \mathrm{N} 53^{\circ} 59^{\prime} \mathrm{E}\right)$, 16.06.2009 (V. Hula).

DIAGNOSIS. Filistata insidiatrix differs from other Mediterranean congeners by the following characters:

- from $F$. puta and $F$. lehtineni sp.n. it can be distinguished by having a different configuration of the eye group, embolus and the spermathecae (cf. Figs. 78, 15-16, 19-22, 25-27 \& Wunderlich, 1995, fig. 24 ); from the former species it differs also by its more intensive (not uniformly pale) coloration;

- from $F$. annulipes it differs in being larger $(>5$ $\mathrm{mm}$ in $F$. insidiatrix and $5<$ in $F$. annulipes $)$ and in 


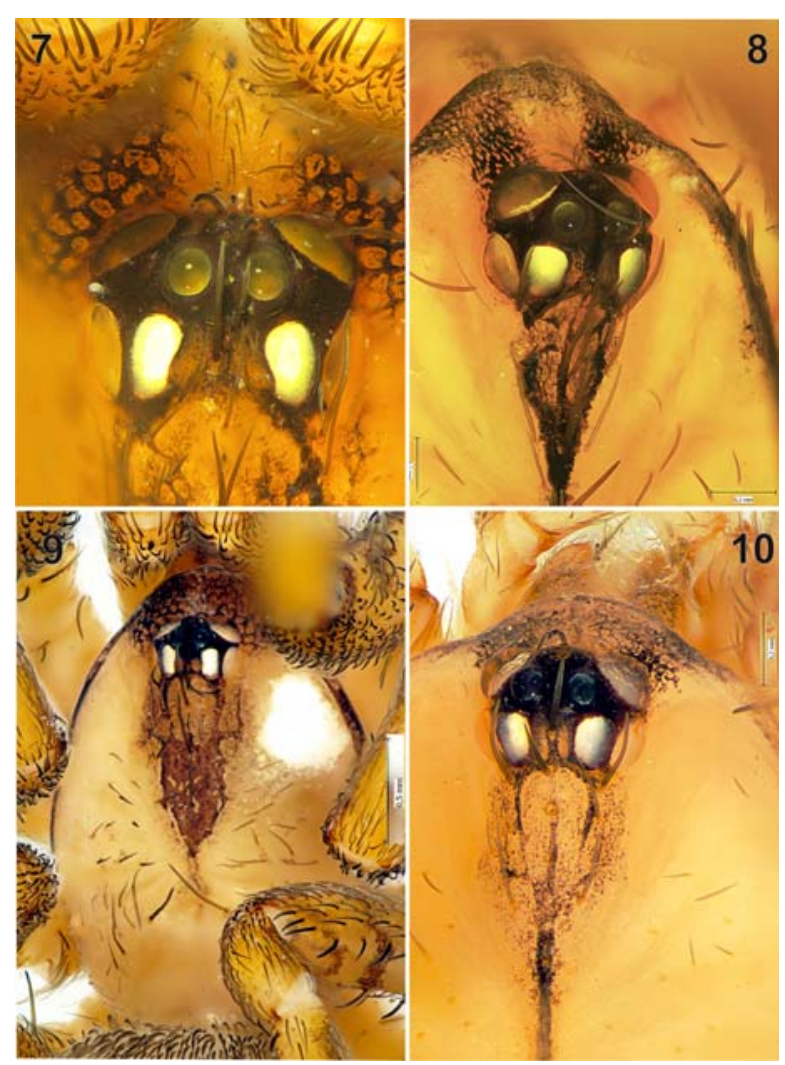

Figs 7-10. Carapace and eyes of Filistata insidiatrix (7-8) and F. lehtineni sp.n. (9-10): 7, 9 - female; 8, 10 - male.

Рис. 7-10. Карапакс и глаза Filistata insidiatrix (7-8) и F. lehtineni sp.n. (9-10): 7, 9 - самка; 8, 10 - самец.

having uniformly coloured legs lacking darker fasciae;

- from F. canariensis Schmidt, 1976, F. gomerensis Wunderlich, 1992, F. pseudogomerensis Wunderlich, 1992, F. teidensis Wunderlich, 1992 and F. tenerifensis Wunderlich, 1992 this species differs by having a noticeably longer cymbium and embolus [ $c f$. Wunderlich, 1992: figs 130-140].

Based on these characters, $F$. insidiatrix can be identified and distinguished from all other Filistata species, even in the juvenile stage.

DESCRIPTION. Well described by Brignoli [1982].

DISTRIBUTION. Filistata insidiatrix is known from the Iberian Peninsula [Helsdingen, 2013] through all of the northern Mediterranean countries to Turkmenistan [Mikhailov, 2013] (Map 1). All records of this species from Macronesia seem to refer to another species [cf. Wunderlich, 1992: 312].

HABITATS. The species occurs within a wide scope of natural biotopes - from semideserts to true broadleaved forest areas; it is also widely known as a synanthropic species [Brignoli, 1982]. In south Azerbaijan it was collected from the wall of a log house. In Turkey (Alanya Prov.) it was seen in great numbers on the roof and walls of a small stony grotto and among small claysandy piles. In the surroundings of Haifa the species was collected within the forest and from the crevices of a stony cliff.

\section{Filistata lehtineni sp.n.}

Figs 4-6, 9-10, 13-14, 17-18, 23-24, 28-29, Map 1.

TYPES. Holotype ơ (ZMMU): AZERBAIJAN, Naxçıvan,

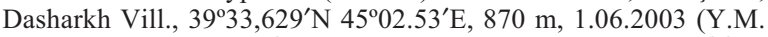
Marusik). Paratypes: 1 ( $q$ MMU), same data as holotype; 2 우, 1 juv. (ZMMU), CE Azerbaijan, Gobustan, stony semidesert, $40^{\circ} 07^{\prime} \mathrm{N}$

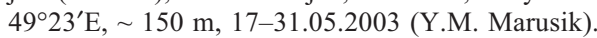

ETYMOLOGY. The species is named after our friend and senior colleague Pekka T. Lehtinen in honour of his profound studies on the systematics of spiders and on occasion of his $80^{\text {th }}$ birthday.

DIAGNOSIS. Males of the new species differ from all other Filistata species by having a screwed embolus (Figs.17-18, 23-24). Both sexes of F. lehtineni sp.n. clearly differ from the sympatric $F$. insidiatrix by having a uniformly dark clypeus (the clypeus has a light median band in F. insidiatrix) (cf. Figs 7-10). The males of the two species have distinctly different palps: distinct spines on palpal femur, short tibia, dorsal setae of cymbium shorter than cymbium and screwed embolus in the new species, whereas $F$. insidiatrix has a femur lacking spines, a long and thin tibia, very long dorsal setae on the cymbium (longer than cymbium), and a straight embolus with a bent tip. Females of $F$. lehtineni sp.n. have smaller receptacles (Figs 28-30) than the sympatric $F$. insidiatrix (Figs 25-27).

DESCRIPTION: Male (holotype). Total length 5.38. Carapace 2.16 long, 1.72 wide. Body light yellowish-
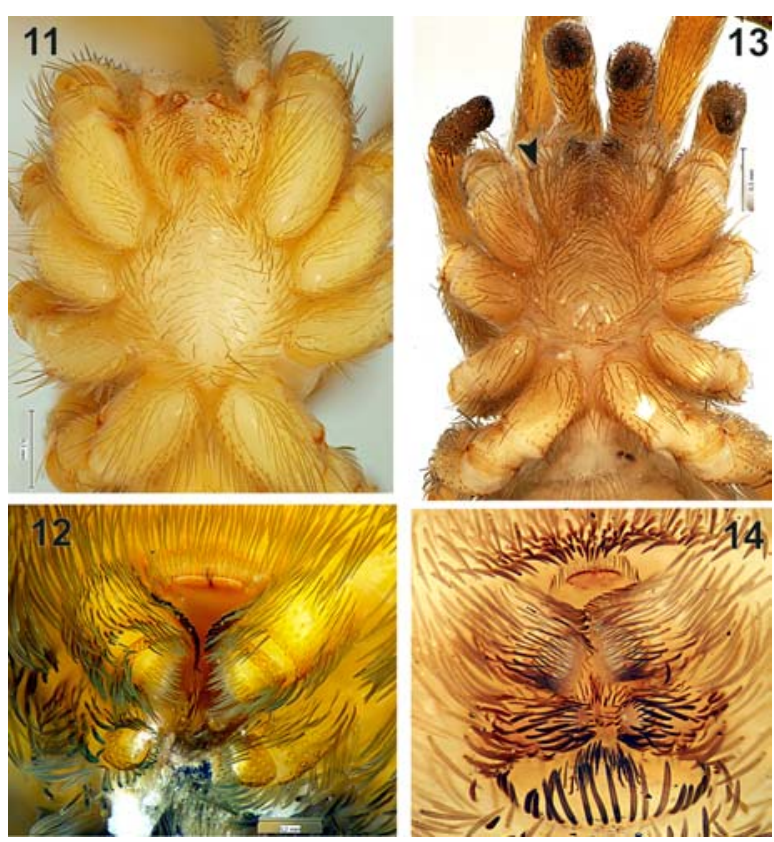

Figs 11-14. Ventral view of female prosoma and spinnerets of Filistata insidiatrix (11-12) and F. lehtineni sp.n. (13-14): 11, 13 - prosoma; 12,14 - spinnerets.

Рис. 11-14. Головогрудь и паутинные бородавки Filistata insidiatrix (11-12) и F. lehtineni sp.n. (13-14) снизу: 11, 13 головогрудь; 12, 14 - бородавки. 

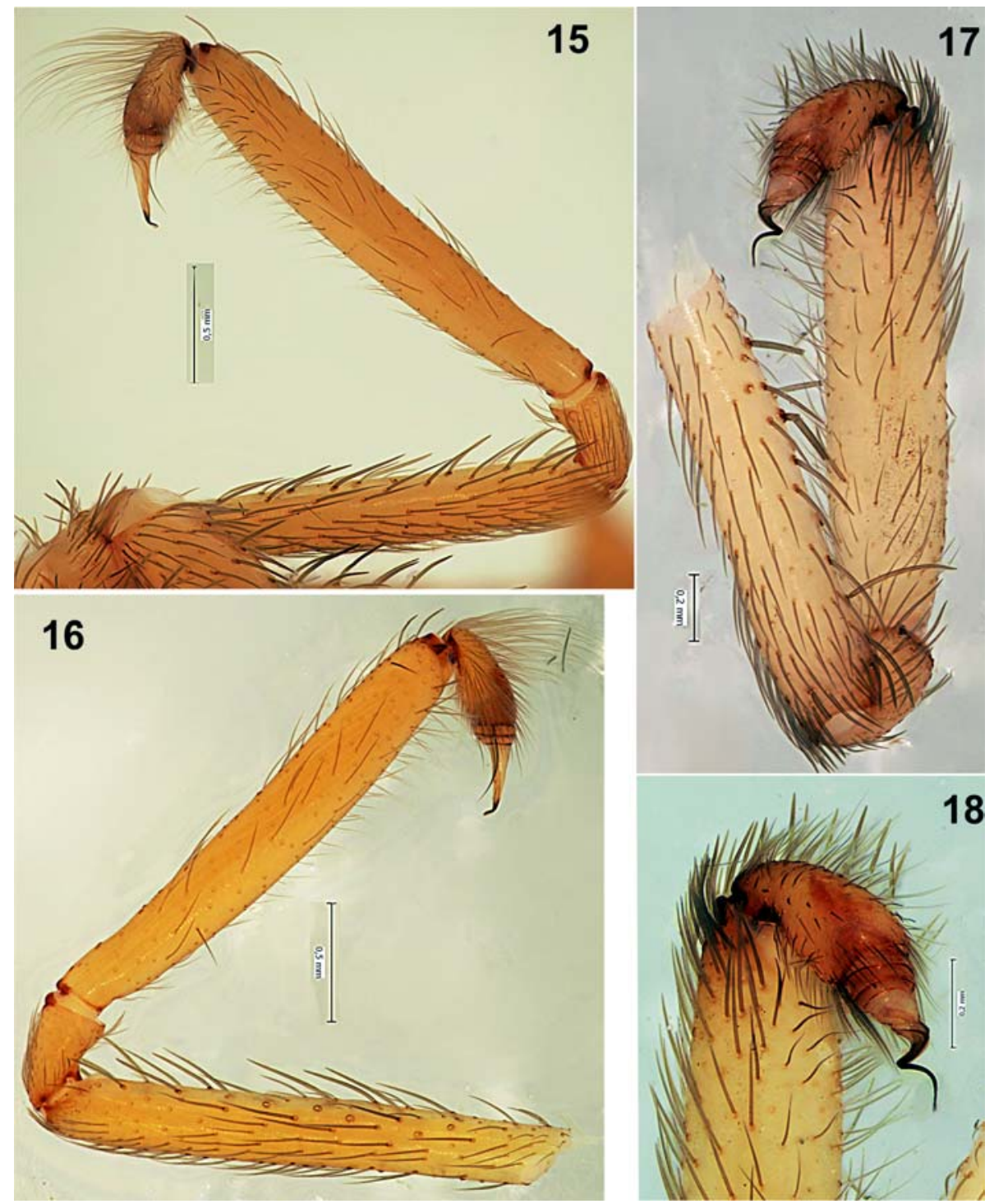

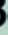

Figs 15-18. Male palp of Filistata insidiatrix $(15-16)$ and $F$. lehtineni sp.n. (17-18): 15, 17 retrolateral, 16, 18 - prolateral.

Рис. 15-18. Пальпа самца Filistata insidiatrix $(15-16)$ и $F$. lehtineni sp.n. (17-18): 15, 17 ретролатерально; 16, 18 - пролатерально.

brown; legs and abdomen uniformly coloured; carapace with dark brown pattern including eye tubercle, postocular area, narrowly marked thoracic fovea and margins. Eye tubercle (Fig. 10) low. Eye diameters: AME 0.08, ALE 0.15, PLE 0.13, PME 0.11. Interdistance AME-AME 0.06. Leg measurements as shown in the table. Palp aspinose. Leg spination: femora: FI d1$0-0, \mathrm{p} 0-4(5)-1, \mathrm{r} 0-0-1$, FII d1-0-0, p0-0-1, FIII d1$0(1)-0, \mathrm{p} 0-0-1$; FIV d1-0-0, p0-0-1, r0-0-1; tibiae: TI p0-0-1-1-1-1, r0-0-1, v0-1-0, r0-0-1; TII p01-1-1; TIII p0-0-1, v1-1-1(2); TIV p0-0-1, r0-1-2; metatarsi: MI p0-1-1-0, v2-2-2(3); MII p0-1-0, v22-3; MIII p0-1-1, v2-2-2-3(4); MIV p0-0-1, v2-22-4; other segments aspinose.

Palp as in Figs 17-18, 23-34. Femur with distinct ventral spines; tibia wider than femur, tibia relatively short (2.4 times longer than cymbium+bulbus); cymbium with short hairs (not longer than cymbium and even shorter than diameter of cymbium), prolateral setae weak; bulbus conical, relatively short; embolus with distinct base, screwed.

Length of leg joints in holotype $\sigma^{7}$ and paratype $q$ (in parentheses):

\begin{tabular}{|l|c|c|c|c|c|c|}
\hline & Femur & Patella & Tibia & Metatarsus & Tarsus & Total \\
\hline Palp & $1.49(1.08)$ & $0.46(0.52)$ & $1.48(0.65)$ & - & $0.39(0.92)$ & $3.82(3.17)$ \\
\hline I & $2.97(2.27)$ & $0.95(0.79)$ & $3.38(2.05)$ & $3.46(1.92)$ & $1.70(1.36)$ & $12.46(8.39)$ \\
\hline II & $2.58(1.71)$ & $0.93(0.63)$ & $2.37(1.29)$ & $2.37(1.28)$ & $1.39(0.89)$ & $9.64(5.80)$ \\
\hline III & $2.20(1.50)$ & $0.72(0.62)$ & $2.20(0.96)$ & $2.39(0.96)$ & $1.22(0.67)$ & $8.73(4.71)$ \\
\hline IV & $3.06(1.97)$ & $0.95(0.80)$ & $2.73(1.24)$ & $3.04(1.26)$ & $1.45(0.87)$ & $11.23(6.14)$ \\
\hline
\end{tabular}




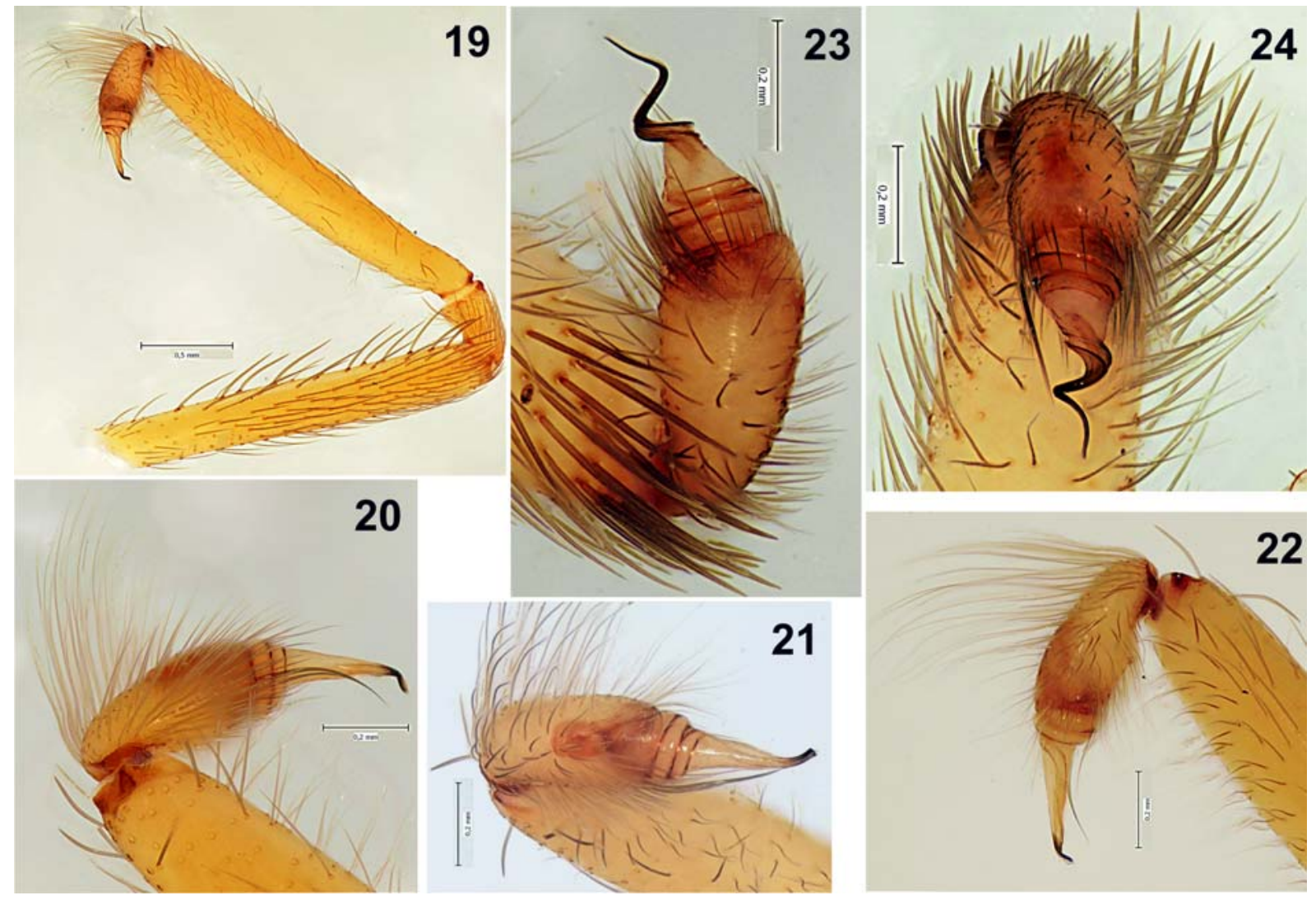

Figs 19-24. Male palp of Filistata insidiatrix (19-22) and F. lehtineni sp.n. (23-24): 19 - whole palp, retrolateral; 20-22 - terminal part of palp, prolateral, subapical and retrolateral; 23-24 - terminal part of palp, retrolateral and apical.

Рис. 19-24. Пальпа самца Filistata insidiatrix (19-22) и F. lehtineni sp.n. (23-24): 19 - вся пальпа, ретролатерально; 20-22 дистальная часть пальпы, пролатерально, субапикально и ретролатерально; 23-24 - дистальная часть пальпы, ретролатерально и апикально.

FEMALE (paratype). Coloration as in male, except somewhat more darker legs and abdomen, which are darker than the carapace (Fig. 5). Total length 6.35. Carapace 2.37 long, 1.62 wide. Eye diameters: AME 0.08, ALE 0.20, PLE 0.16, PME 0.11. Interdistance AME-AME 0.06. Leg measurements as shown in the table. Leg spination: FI-IV d1-0-0; MI-II v1-0-3(4); MIII-IV v1-1-3(4); elsewhere spines absent. Labium, sternum, and spinnerets as shown in Figs 13-14. Endogyne as in Figs 28-30. Receptacles round, not subdivided, separated by about four times their diameter.

VARIATION. Carapace length in females varies from 2.2 to 2.4; the peculiarities of the coloration are stable within the whole type series.

DISTRIBUTION. Southwestern and Eastern Azerbaijan: in foothills.

HABITATS. All specimens were collected in clayey and rocky semidesert areas.

ACKNOWLEDGEMENTS. We are grateful to all colleagues who supplied us with identified and unidentified material of Filistata from different parts of the Mediterranean, and particularly the following curators of museums: Kirill Mikhailov (ZMMU), the late Gershom Levi (HUJ), Dmitri Logunov (MMUM), Pekka Lehtinen and Seppo Ko- ponen (ZMUT). Special thanks go to S. Koponen who arranged our stay in Turku and provided working facilities. The manuscript was reviewed by Dmitry V. Logunov and Mykola M. Kovblyuk (Simferopol). The senior author also thanks colleagues and partners of the expedition to Azerbaijan: Khalid Aliev, Elchin Huseynov and Natalia Snegovaya (Baku). The English of the final draft was kindly checked and corrected by David Penney (Manchester). This project was supported in part by the Russian Foundation for Fundamental Research (grant \# 12-04-01548) and by the Ministry of Absorption, Israel.

\section{References}

Brignoli P.M. 1978. Some remarks on the relationships between the Haplogynae, the Semientelegynae and the Cribellatae // Symp. zool. Soc. Lond. Vol.42. P.285-292.

Brignoli P.M. 1982. Contribution à la connaissance des Filistatidae paléarctiques (Araneae) // Revue arachnologique. T.4. P.6575.

Dunin P.M. 1984. [Fauna and ecology of the spiders of the Apscheron Peninsula, Azerbaidjan SSR] // Fauna i ekologiya paukoobraznykh. Perm: Perm University. P.45-60 [in Russian].

Dunin P.M. 1988. [Cribellate spiders (Aranei, Cribellatae) of Azerbaijan] // Entomologicheskoe Obozrenie. Vol.67. Nr.4. P.190203 [in Russian]. 

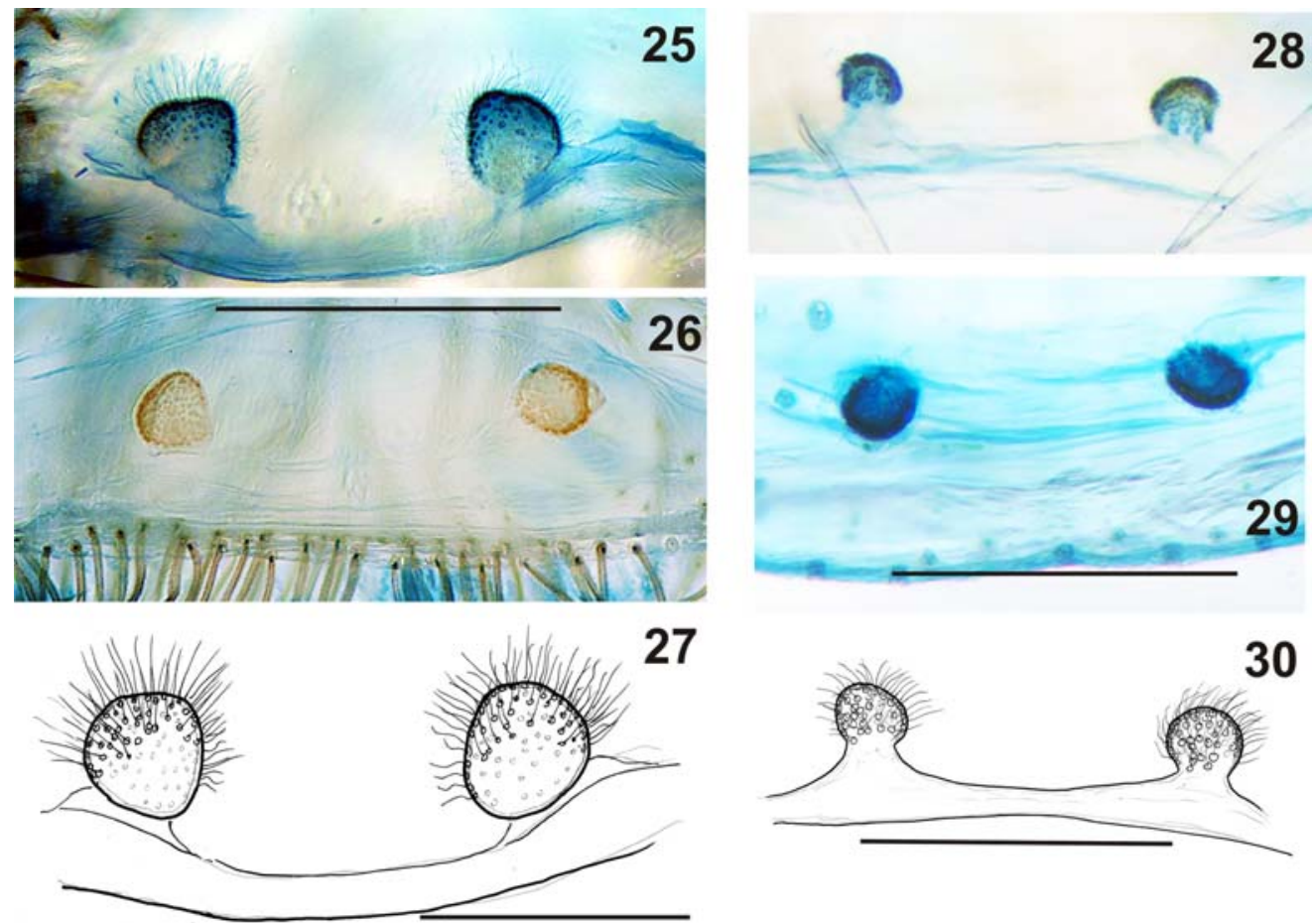

Figs 25-30. Endogyne of Filistata insidiatrix (25-27) and F. lehtineni sp.n. (28-30): 25, 27, 28, 30 - dorsal; 26, 29 - anterior. Рис. 25-30. Эндогина Filistata insidiatrix (25-27) и F. lehtineni sp.n. (28-30): 25, 27, 28, 30 - сверху; 26, 29 - спереди.

Fet V.Y. 1983. [The fauna of Aranei of South-Western Kopetdagh] // Entomologicheskoe Obozrenie. Vol.62. Nr.4. P.835-845 [in Russian].

Ghahari H., Marusik Yu.M. 2009. New data on spider fauna of Iran (Araneae) // Turkish Journal of Arachnology. Vol.2. No.3. P.1-8.

Helsdingen P.J. 2013. Araneae // Fauna Europaea Database European spiders and their distribution - Distribution - Version 2013.1

Kunt K.B., Yağmur E.A., Elverici M. 2008. The cave dwelling arthropods of Dim cave (Turkey: Antalya: Alanya) // Munis Entomology \& Zoology. Vol.3. Nr.2. P.682-690.

Mikhailov K.G. 2013. The spiders (Arachnida: Aranei) of Russia and adjacent countries: a non-annotated checklist // Arthropoda Selecta. Supl. No.3. 262 p.

Mkheidze T. 1997. [Spiders of Georgia: Systematics, ecology, zoogeographic review]. Tbilisi University, $390 \mathrm{pp}$. [in Georgian]

Platnick N.I. 2014. The world spider catalog, version 14.5. American Museum of Natural History; online at: ttp://research. amnh. org/entomology/spiders/catalog/index.html (accessed January 20, 2014).

Roewer C.F. 1959. Die Araneae, Solifuga und Opiliones der Sammlungen des Herrn Dr. K. Lindberg aus Griechenland, Creta,
Anatolien, Iran und Indien // Meddelanden från Göteborgs Musei. Bd.129. Ser.B. Nr.8(4). P.1-47.

Spassky S.A. 1937. [Materials to the spider fauna of the Black Sea coast] // Sbornik nauchno-issled. rabot Azovo-Chernomorskogo selskokhoz. inst. Vol.5. P.131-138 [in Russian].

Spassky S. 1952. [Spiders of Turan zoogeographical province] // Entomol. Obozr. Vol.32. P.192-205 [in Russian].

Strand E. 1913. Erste Mitteilung über Spinnen aus Palästina, gesammelt von Herrn Dr J. Aharoni // Archiv für Naturgeschichte, Berlin. Bd.79. Abt.10. S.147-162.

Wunderlich J. 1992. Die Spinnen-Fauna der Makaronesischen Inseln: Taxonomie, Ökologie, Biogeographie und Evolution // Beiträge zur Araneologie. Bd.1. 619 S.

Wunderlich J. 1995. Beschreibung des fraglichen Männchens von Filistata puta O. Pickard-Cambridge 1876 aus Algerien (Arachnida: Araneae: Filistatidae) // Beiträge zur Araneologie. Bd.4 (für 1994). S.617-619.

Wunderlich J. 2011. Extant and fossil spiders (Araneae) // Beiträge zur Araneologie. Bd.6. P.1-640.

Responsible editor Seppo Koponen 